\title{
PENGARUH RETURN ON ASSET (ROA) DAN DEBT TO EQUITY RATIO (DER) TERHADAP PERTUMBUHAN LABA PADA PERUSAHAAN SUB SEKTOR MAKANAN DAN MINUMAN YANG TERCATAT DI BEI PERIODE 2015-2019
}

\author{
Erick Agustinus \\ Universitas Pamulang \\ Email: agustinusrick@gmail.com
}

\begin{abstract}
Purpose. The purpose of this study was to analyze the effect of Return On Assets and Debt to Equity on Profit Growth of Food and Beverage Sub-Sector Companies Listed on the Indonesia Stock Exchange for the 2015-2019 Period.

Methods. Causality method used in research. The population in this study are food and beverage companies in Indonesia (IDX) for the 2015-2019 period. Sample selection using a purposive sampling technique. The selected sample is 13 companies. The method of analysis in this study consisted of a classical assumption test, multiple linear regression analysis test, t-test, $F$ test, and $R^{2}$ test.

Findings. The results of hypothesis testing indicate that individually the Return On Assets variable has a negative and insignificant effect on the Profit Growth variable, Debt to Equity Ratio has a positive and significant effect on the Profit Growth variable, while simultaneously Return On Assets and Debt to Equity Ratio have a positive and significant effect on Profit Growth variable.
\end{abstract}

Implication. The company should be able to change certain current assets such as collection of receivables or selling inventory into cash to pay current debts that are not more than one year so that current assets can guarantee current liabilities.

Keywords. Return On Assets, Debt To Equity Ratio, Profit Growth.

\begin{abstract}
ABSTRAK
Tujuan. Tujuan penelitian ini adalah untuk menganalisis pengaruh Return On Asset dan Debt to Equity terhadap Pertumbuhan Laba pada Perusahaan Sub Sektor Makanan dan Minuman Yang Tercatat di BEI Periode 2015-2019.

Metode. Metode Kausalitas digunakan dalam penelitian ini. Populasi dalam penelitian ini adalah perusahaan makanan dan minuman yang terdaftar di Bursa Efek Indonesia (BEI) periode 2015-2019. Pemilihan sampel menggunakan tehnik Purposive Sampling. Sampel yang terpilih sebanyak 13 perusahaan. Metode analisis dalam penelitian ini terdiri dari, uji asumsi klasik, uji analisis regresi linier berganda, uji t, uji F, dan uji R².

Hasil. Hasil pengujian hipotesis menunjukkan bahwa secara individu variabel Return On Asset berpengaruh negatif dan tidak signifikan terhadap variabel Pertumbuhan Laba, Debt to Equity Ratio berpengaruh positif dan signifikan terhadap variabel Pertumbuhan Laba, sedangkan secara serempak Return On Asset dan Debt to Equity Ratio berpengaruh positif dan signifikan terhadap variabel Pertumbuhan Laba.
\end{abstract}


Implikasi. Sebaiknya perusahaan bisa mengubah aktiva lancar tertentu seperti penagihan piutang atau menjual persediaan menjadi kas untuk membayar utang lancarnya yang tidak lebih dari satu tahun supaya aktiva lancar dapat menjamin hutang lancar yang ada.

Kata Kunci : Return On Asset, Debt To Equity Ratio, Pertumbuhan Laba

\section{Pendahuluan}

Perusahaan makanan dan minuman merupakan salah satu sektor usaha yang terus mengalami pertumbuhan. Seiring dengan meningkatnya pertumbuhan jumlah penduduk di Indonesia, volume kebutuhan terhadap makanan dan minuman pun terus meningkat pula. Kecenderungan masyarakat Indonesia untuk menikmati makanan siap saji ini menyebabkan banyak bermunculan perusahaan-perusahaan baru di bidang makanan dan minuman karena mereka menganggap sektor industri food dan beverages memiliki prospek yang menguntungkan baik masa sekarang maupun yang akan datang (Nur, 2016).

Pertumbuhan laba yang maksimal akan mengakibatkan kesuksesan dan keberhasilan bagi perusahaan. Menurut Ningsih, Hasanah, dan Prihatni (2017) "pertumbuhan laba merupakan perntase kenaikan laba yang diperoleh perusahaan. Laba akan meningkat atau menurun tiap tahunnya, dengan demikian, apabila rasio keuangan perusahaan baik, maka pertumbuhan laba perusahaan juga baik".

Fahmi (2016) berpendapat bahwa "return on assets (ROA) merupakan rasio yang mengukur sejauh mana kemampuan perusahaan menghasilkan laba bersih berdasarkan total asset yang dimilikinya". Semakin tinggi nilai ROA semakin tinggi pula tingkat laba yang dihasilkan, sehingga ROA dapat dijadikan sebagai alat untuk memprediksi laba (Hidayat, 2014).

Debt to equity ratio (DER) merupakan rasio solvabilitas untuk menunjukan kemampuan suatu perusahaan dalam membayar kewajiban jangka pendek dan kewajiban jangka panjang. Besar atau kecilnya rasio DER akan mempengaruhi tingkat pencapaian laba perusahaan. Semakin besar rasio DER akan semakin baik, sebaliknya dengan rasio DER yang rendah semakin tinggi tingkat pendanaan yang disediakan pemilik dan semakin besar batas pengamanan bagi peminjam jika terjadi kerugian atau penyusutan terhadap nilai aktiva, besar atau kecilnya DER akan mempengaruhi tingkat pencapaian laba perusahaan (Fitriati, 2021:60).

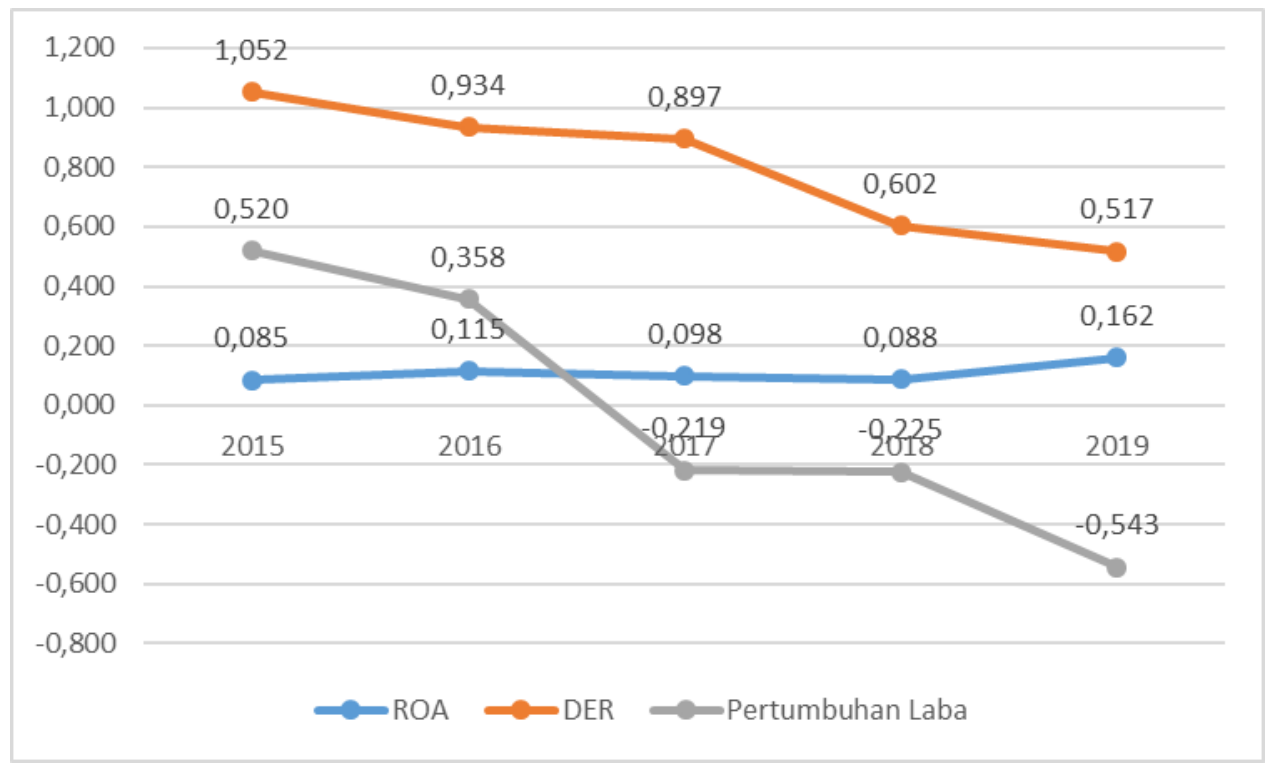

Sumber : Data diolah Penulis (2021)

Gambar 1. Grafik ROA, DER dan Pertumbuhan Laba Periode 2015 - 2019 
Berdasarkan gambar 1 ditemukan beberapa fenomena yang terjadi bahwa rata-rata return on assets (ROA) mengalami kenaikan pada tahun 2015 ke 2016 namun return on assets (ROA) di perusahaan makanan dan minuman yang terdaftar di BEI pada tahun 2017 dan tahun 2018 cenderung mengalami penurunan dan pada tahun 2019 meningkat menajdi 0,162. Nilai profit yang rendah menunjukan bahwa perusahaan tidak begitu berhasil karena tidak efisien dan tidak efektifnya produksi, distribusi, keuangan atau manajemen umum, yaitu kondisi umum perusahaan yang tidak menguntungkan atau kelebihan investasi dalam aktiva.

Pada variabel DER dapat dilihat bahwa keadaan debt to equity ratio perusahaan makanan dan minuman cenderung menurun. Penurunan debt to equity ratio mengartikan bahwa hutang perusahaan lebih kecil dari pada ekuitasnya. jika jumlah hutang sudah melebihi jumlah ekuitas yang dimiliki maka risiko perusahaan dari sisi likuiditas keuangan akan semakin tinggi. Pada variabel pertumbuhan laba yang dihasilkan perusahaan makanan dan minuman tidak baik pada setiap periodenya. Terlihat bahwa pertumbuhan laba perusahaan makanan dan minuman pada tahun 2015 - 2019 menurun tajam hingga mencapai angka negatif, hal itu dikarenakan terdapat perusahaan yang memiliki pertumbuhan laba negatif yang memberikan pengaruh begitu besar bagi pertumbuhan laba perusahaan makanan dan minuman.

Berdasarkan fenomena tersebut, motivasi penelitian ini adalah perusahaan manufaktur sub sektor makanan dan minuman merupakan perusahaan yang sangat dibutuhkan oleh masyarakat sehingga prospek untuk perusahaain ini sangat baik dimasa sekarang maupun dimasa yang akan datang, dengan harga saham yang tinggi membuat nilai perusahaan juga tinggi sehingga akan membuat pasar percaya atas prospek perusahaan makanan dan minuman.

Berdasarkan dari uraian diatas maka penulis tertarik untuk menyusun penelitian dengan judul "Pengaruh Return on Asset (ROA) Dan Debt to Equity Ratio (DER) Terhadap Pertumbuhan Laba Pada Perusahaan Sub Sektor Makanan Dan Minuman Yang Tercatat di BEI Periode 2015-2019".

\section{Kajian Pustaka dan Hipotesis}

Return on Asset (ROA). Fahmi (2016:98) mengatakan "return on assets sering juga disebut sebagai return on investment, karena ROA ini melihat sejauh mana investasi yang telah ditanamkan mampu memberikan pengembalian keuntungan sesuai dengan yang diharapkan dan investasi tersebut sebenarnya sama dengan aset perusahaan yang ditanamkan atau ditempatkan". Sedangkan menurut Kasmir (2016:237) "ROA digunakan untuk mengukur kemampuan manajemen dalam memperoleh profitabilitas dan manajerial efisiensi secara keseluruhan". Secara matematis dapat dirumuskan sebagai berikut:

ROA $=\frac{\text { Laba Sebelum Pajak }}{\text { Total Aktiva }}$ X100\%

Semakin besar ROA perusahaan, Semakin besar perusahaan dan lokasi yang lebih baik Perusahaan menggunakan aktiva. Oleh karena itu, untuk manajemen atau Profitabilitas pihak lain Tinggi lebih penting daripada untung Yang besar. Profitabilitas perusahaan Dengan kesuksesan perusahaan dan Kemampuan untuk menggunakan aset secara efektif Produktivitas dan dengan demikian keuntungan Perusahaan dapat diidentifikasi dengan cara berikut: Keuntungan komparatif Diperoleh selama periode waktu tertentu Total aset atau total modal perusahaan.

Debt to Equity Ratio (DER). Menurut Sukamulja (2017:50) “Debt to equity ratio (DER) adalah mengukur persentase liabilitas pada struktur modal perusahaan. Rasio ini penting untuk mengukur risiko bisnis perusahaan yang semakin meningkat dengan penambahan jumlah liabilitas". Menurut Kasmir (2016:157) "Debt to Equity Ratio merupakan rasio yang digunakan untuk menilai utang dengan ekuitas". Debt To Equity ratio dapat dihitung dengan menggunakan rumus: 
$\mathrm{DER}=\frac{\text { Total Hutang }}{\text { Total Equity }}$

Bagi perusahaan, semakin besar rasionya, semakin baik. Jika tidak Semakin rendah rasionya, semakin tinggi tingkat pendanaan yang diberikan Pemilik, jika terjadi kerugian atau peminjam, semakin besar batas jaminan peminjam the Depresiasi nilai aset.

Pertumbuhan Laba. Menurut Ikatan Akuntansi Indonesia (2012:12), "Penghasilan bersih (laba) sering digunakan sebagai ukuran kinerja atau dasar bagi ukuran yang lain seperti imbal hasil investasi (Return On Investment) atau laba per saham (Earning Per Share)". Menurut Juliana, Kasmawati, dan Tanjung (2020:377) "Pertumbuhan laba merupakan menunjukkan persentase kenaikan laba yang dapat dihasilkan perusahaan dalam bentuk laba bersih". Menurut Ningsih. Hasanadan Prihatni (2017) pertumbuhan laba merupakan persentase kenaikan laba yang diperoleh perusahaan. Laba akan meningkat atau menurun tiap tahunnya. Peningkatan atau penurunan inilah yang disebut pertumbuhan laba.

$\mathrm{Y}=\frac{\mathrm{Yt}-\mathrm{Yt}-{ }_{1}}{\mathrm{Yt}-{ }_{1}}$

Pertumbuhan laba dihitung dengan cara mengurangkan laba bersih tahun ini dengan laba bersih tahun lalu kemudian dibagi dengan laba bersih tahun lalu. Laba yang dimaksudkan dalam penelitian ini adalah laba EAT (Earning After Tax) yaitu laba bersih setelah pajak.

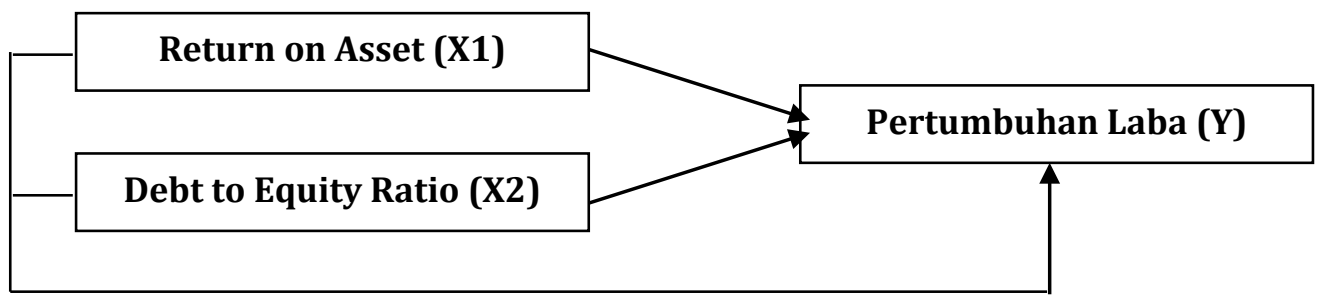

Gambar 2. Model Penelitian

\section{Hipotesis}

H1: Diduga Return on Asset berpengaruh terhadap pertumbuhan Laba

H2: Diduga Debt to Equity Ratio berpengaruh terhadap pertumbuhan Laba

H3: Diduga Return on Asset dan Debt to Equity Ratio secara simultan berpengaruh terhadap pertumbuhan Laba

\section{Metode Penelitian}

Jenis penelitian ini adalah penelitian kuantitatif dengan sebab akibat (comparative causation) karena bertujuan untuk menguji kausalitas antara dua variabel, yaitu variabel bebas dan variabel terikat. Metode kuantitatif dapat diartikan sebagai metode penelitian yang didasarkan pada filosofi politik yang digunakan untuk menguji populasi atau sampel tertentu, pengumpulan data menggunakan alat penelitian, analisis data kuantitatif atau statistik untuk menguji hipotesis yang telah ditetapkan. Jenis data yang digunakan dalam penelitian ini adalah data sekunder, yaitu laporan keuangan perusahaan sub sektor makanan dan minuman yang tercatat di BEI periode 2015-2019 melalui situs resmi BEI yaitu www.idx.co.id.

Populasi yang digunakan dalam penelitian ini adalah seluruh perusahaan sub sektor makanan dan minuman yang tercatat di BEI periode 2015-2019 dengan jumlah 30 perusahaan. Dan jumlah perusahaan industri sub sektor makanan dan minuman yang terpilih menjadi sampel penelitian ini adalah 13 perusahaan dikalikan dengan 5 tahun penelitian sehingga jumlah observasi penelitian sebanyak 65 data. 


\section{Hasil Penelitian dan Pembahasan Statistik Deskriptif}

Tabel 1. Statistik Deskriptif

\begin{tabular}{|l|c|c|c|}
\hline & ROA & DER & Pertumbuhan Laba \\
\hline Mean & 0,1094 & 0,7997 & $-0,0217$ \\
\hline Std. Deviation & 0,13429 & 0,67904 & 1,48734 \\
\hline Minimum & $-0,10$ & $-2,13$ & $-10,19$ \\
\hline Maximum & 0,61 & 1,90 & 2,05 \\
\hline Sum & 7,11 & 51,98 & $-1,41$ \\
\hline
\end{tabular}

Sumber: Data diolah SPSS 26 (2021)

Variabel ROA mempunyai rentangan antara -0,10 sampai 0,61 dengan rata-rata sebesar 0,1094 dan Std. Deviation sebesar 0,13429. DER mempunyai rentangan antara -2,13 sampai 1,90 dengan rata-rata sebesar 0,7997 dan Std. Deviation sebesar 0,67904. Variabel Pertumbuhan Laba mempunyai rentang antara -10,19 sampai 2,05 dengan rata-rata sebesar 0,0217 dan Std. Deviation sebesar 1,48734.

\section{Uji Asumsi Klasik}

\section{Uji Normalitas}

Menurut Ghozali, (2016) bahwa uji normalitas dapat bertujuan untuk menguji apakah model regresi yang digunakan dalam penelitian, variabel dependen, indepen, dan dalam penelitian ini juga di gunakan variabel kontrol memiliki distribusi normal atau tidak.

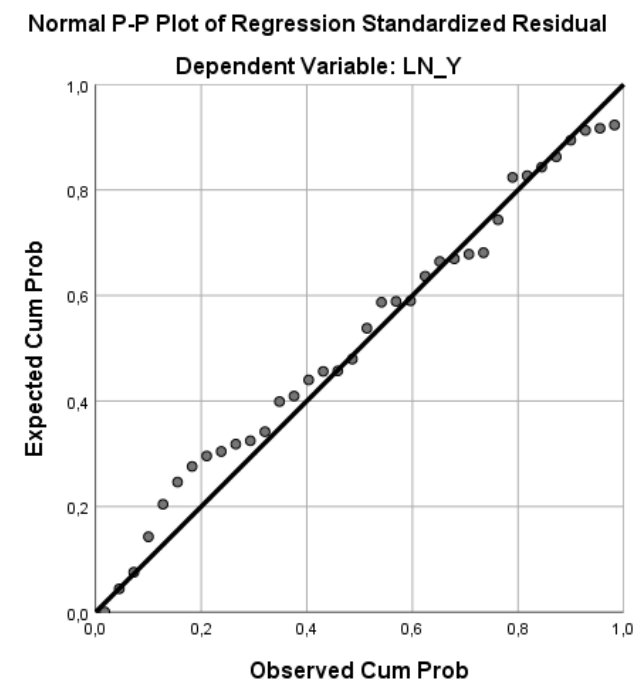

Gambar 3. Hasil Uji Normalitas

Dengan melihat tampilan gambar grafik normal P-plot, terlihat titik-titik menyebar berhimpit di sekitar garis diagonal dan hal ini menunjukkan bahwa data telah terdistribusi secara normal.

\section{Uji Multikolineritas}

Menurut (Ghozali, 2016) menyatakan bahwa deteksi adanya multikolinearitas dapat dilihat dari besaran VIF dan tolerance, dengan ketentuan sebagai berikut:

1) Jika nilai tolerance $<0,1$ dan VIF $>10$, terjadi multikolinearitas.

2) Jika nilai tolerance $>0,1$ dan $\mathrm{VIF}<10$, tidak terjadi multikolinearitas.

Hasil dari pengujian data tersebut adalah sebagai berikut: 
Tabel 2. Hasil Uji Multikolineritas

\begin{tabular}{|c|c|c|c|c|c|c|c|c|}
\hline & \multirow[t]{2}{*}{ Model } & \multicolumn{2}{|c|}{$\begin{array}{c}\text { Unstandardized } \\
\text { Coefficients }\end{array}$} & \multirow{2}{*}{$\begin{array}{c}\text { Standardized } \\
\text { Coefficients }\end{array}$} & \multirow[t]{2}{*}{$\mathrm{t}$} & \multirow[t]{2}{*}{ Sig. } & \multicolumn{2}{|c|}{$\begin{array}{c}\text { Collinearity } \\
\text { Statistics }\end{array}$} \\
\hline & & B & Std. Error & & & & Tolerance & VIF \\
\hline \multirow[t]{3}{*}{1} & (Constant) & $-0,564$ & 0,311 & & $-1,810$ & 0,075 & & \\
\hline & ROA & $-1,988$ & 1,249 & $-0,180$ & $-1,592$ & 0,117 & 0,940 & 1,063 \\
\hline & DER & 0,950 & 0,247 & 0,434 & 3,845 & 0,000 & 0,940 & 1,063 \\
\hline
\end{tabular}

a. Dependent Variable: Pertumbuhan Laba

Sumber: Data diolah SPSS 26 (2021)

Berdasarkan hasil tabel pada data di atas, dapat disimpulkan bahwa kedua variabel bebas independent yaitu ROA dan DER Tidak memiliki multikolinearitas karena nilai variance inflation factor (VIF) $<10$ dan nilai tolerance $>0,10$.

\section{Uji Heteroskedastisitas}

Uji heterokedastisitas digunakan untuk mengetahui apakah dalam model regresi terjadi ketidaksamaan varians dari residual satu pengamatan ke pengamatan yang lain.

Tabel 3. Hasil Uji Heteroskedastisitas

\begin{tabular}{|c|c|c|c|c|c|c|}
\hline \multirow{2}{*}{\multicolumn{2}{|c|}{ Model }} & \multicolumn{2}{|c|}{$\begin{array}{l}\text { Unstandardized } \\
\text { Coefficients }\end{array}$} & $\begin{array}{l}\text { Standardized } \\
\text { Coefficients }\end{array}$ & \multirow[t]{2}{*}{$\mathrm{t}$} & \multirow[t]{2}{*}{ Sig. } \\
\hline & & $\mathrm{B}$ & Std. Error & Beta & & \\
\hline \multirow[t]{3}{*}{1} & (Constant) & 1,196 & 0,339 & & 3,534 & 0,001 \\
\hline & ROA & $-0,774$ & 1,417 & $-0,094$ & $-0,546$ & 0,588 \\
\hline & DER & $-0,227$ & 0,324 & $-0,121$ & $-0,702$ & 0,487 \\
\hline
\end{tabular}

a. Dependent Variable: AbsRes

Sumber: Data diolah SPSS 26 (2021)

Hasil uji heteroskedastisitas dengan menggunakan uji Glejser pada tabel 3 menunjukkan nilai probabilitas signifikansinya diatas 0,05 (5\%). Jadi, dapat disimpulkan bahwa model regresi yang digunakan tidak terdapat adanya heteroskedastisitas.

\section{Uji Autokorelasi}

Cara untuk mengetahunya apakah terjadi atau tidaknya korelasi dapat dilakukan melalui uji Durbin Watson atau DW test. Uji DW test ini membuktikan apakah ada nya korelasi didalam model regresi yang kita gunakan, melalui bagian dari uji statistik SPSS.

Tabel 4. Hasil Uji Autokorelasi

\begin{tabular}{|c|c|c|c|c|c|}
\hline Model & $\mathrm{R}$ & $\mathrm{R}$ Square & $\begin{array}{c}\text { Adjusted R } \\
\text { Square }\end{array}$ & $\begin{array}{c}\text { Std. Error of the } \\
\text { Estimate }\end{array}$ & $\begin{array}{c}\text { Durbin- } \\
\text { Watson }\end{array}$ \\
\hline 1 &, $508^{\mathrm{a}}$ & 0,258 & 0,234 & 1,30136 & 1,857 \\
\hline
\end{tabular}

a. Predictors: (Constant), DER, ROA

b. Dependent Variable: Pertumbuhan Laba

Sumber: Data diolah SPSS 26 (2021)

Nilai DW adalah 1,857. Selanjutnya autokorelasi dalam penelitian ini adalah DU $=1,660$, $\mathrm{DW}=1,857$ dan 4-DU= 4- 1,6044 =2,34. Maka didapati hasil 1,660 $<1,857>2,34$, yang berarti tidak terdapat gejala autokorelasi.

\section{Uji Regresi Linier Berganda}

Setelah dilakukan uji asumsi klasik dan dapat disimpulkan bahwa data yang ada dan digunakan untuk penelitian telah terdistribusi normal dan tidak terdapat multikolinearitas, heteroskedastisitas dan autokorelasi, sehingga memenuhi syarat untuk dilakukan analisis linear berganda. 
Tabel 5. Hasil Regresi Linier Berganda

\begin{tabular}{|c|c|c|c|c|c|c|}
\hline \multirow{2}{*}{\multicolumn{2}{|c|}{ Model }} & \multicolumn{2}{|c|}{$\begin{array}{l}\text { Unstandardized } \\
\text { Coefficients }\end{array}$} & $\begin{array}{l}\text { Standardized } \\
\text { Coefficients }\end{array}$ & \multirow[t]{2}{*}{$\mathrm{t}$} & \multirow[t]{2}{*}{ Sig. } \\
\hline & & B & Std. Error & Beta & & \\
\hline \multirow[t]{3}{*}{1} & (Constant) & $-0,564$ & 0,311 & & $-1,810$ & 0,075 \\
\hline & ROA & $-1,988$ & 1,249 & $-0,180$ & $-1,592$ & 0,117 \\
\hline & DER & 0,950 & 0,247 & 0,434 & 3,845 & 0,000 \\
\hline
\end{tabular}

a. Dependent Variable: Pertumbuhan Laba

Sumber: Data diolah SPSS 26 (2021)

$Y=-0,564-1,988 X_{1}+0,950 X_{2}$

Berdasarkan tabel di atas, maka dapat dikemukakan penjelasan sebagai berikut:

a. Nilai konstanta (a) sebesar -0,564, artinya tanpa variabel bebas ROA dan DER maka variabel terikat pertumbuhan laba akan mencapai -0,564.

b. Nilai koefisien regresi ROA $\left(\mathrm{X}_{1}\right)$ adalah negatif, yaitu $-1,988$, yaitu setiap kenaikan ROA $\left(\mathrm{X}_{1}\right)$ sebesar $1 \%$ maka pertumbuhan laba akan turun sebesar $-1,988$.

c. Koefisien regresi DER $\left(\mathrm{X}_{2}\right)$ bernilai positif sebesar 0,950, yaitu setiap kenaikan DER $\left(\mathrm{X}_{2}\right)$ sebesar 1\% maka pertumbuhan laba akan meningkat sebesar 0,950.

\section{Uji Hipotesis}

Setelah dilakukan uji asumsi klasik maka untuk mengetahui apakah persamaan regresi yang kita pertanggungjawabkan itu dapat dilakukan pengujian hipotesis.

\section{Hipotesis Parsial}

Berdasarkan Tabel 5, hasil dari uji t yaitu pengujian hipotesis ROA $\left(\mathrm{X}_{1}\right)$ terhadap pertumbuhan laba $(Y)$. Dari hasil perhitungan $t$-hitung $(-, 1,592)<t$-tabel $(1,998)$ atau sig $t$ $(0,117)>0,05$; dengan demikian H1 ditolak dan Ho diterima, hal ini berarti tidak terdapat pengaruh antara Return On Asset terhadap Pertumbuhan Laba.

Berdasarkan Tabel 5, Pada variabel DER dari uji t yaitu pengujian hipotesis DER $\left(\mathrm{X}_{2}\right)$ terhadap pertumbuhan laba $(Y)$. Dari hasil perhitungan t-hitung $(3,845)>t$-tabel $(1,998)$ atau sig $\mathrm{t}(0,00)>0,05$; dengan demikian $\mathrm{H} 1$ diterima dan Ho ditolak, hal ini berarti terdapat pengaruh antara Debt to Equity Ratio terhadap Pertumbuhan Laba.

\section{Hipotesis Simultan}

Untuk menunjukkan apakah semua variabel independen yang dimasukkan dalam model mempunyai pengaruh secara bersama sama terhadap variabel dependen sehingga apakah model dapat digunakan untuk memprediksi variabel dependen maka dilakukanlah uji statistik F sebagai berikut :

Tabel 6. Hasil Uji F Simultan

\begin{tabular}{|c|l|r|r|r|r|l|}
\hline \multicolumn{2}{|c|}{} & $\begin{array}{c}\text { Sum of } \\
\text { Squares }\end{array}$ & df & $\begin{array}{c}\text { Mean } \\
\text { Square }\end{array}$ & F & \multicolumn{1}{c|}{ Sig. } \\
\hline \multirow{2}{*}{1} & Regression & 36,580 & 2 & 18,290 & 10,800 &, $000^{\mathrm{b}}$ \\
\cline { 2 - 7 } & Residual & 105,000 & 62 & 1,694 & & \\
\cline { 2 - 7 } & Total & 141,580 & 64 & & & \\
\hline
\end{tabular}

a. Dependent Variable: Pertumbuhan Laba

b. Predictors: (Constant), DER, ROA

Sumber: Data diolah SPSS 26 (2021)

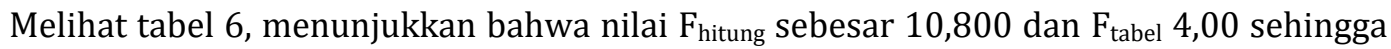
$F_{\text {hitung }} 10,800>F_{\text {tabel }} 4,00$ dan nilai sig. 0,000 < tingkat signifikan 0,05. Maka dapat dinyatakan bahwa return on asset dan debt to equity ratio secara simultan berpengaruh positif dan signifikan terhadap pertumbuhan laba. 
Tabel 7. Hasil Uji Koefisien Determinasi

\begin{tabular}{|c|c|c|c|c|c|}
\hline Model & $\mathrm{R}$ & $\mathrm{R}$ Square & $\begin{array}{c}\text { Adjusted R } \\
\text { Square }\end{array}$ & $\begin{array}{c}\text { Std. Error of the } \\
\text { Estimate }\end{array}$ & $\begin{array}{c}\text { Durbin- } \\
\text { Watson }\end{array}$ \\
\hline 1 &, $508^{\mathrm{a}}$ & 0,258 & 0,234 & 1,30136 & 1,857 \\
\hline
\end{tabular}

a. Predictors: (Constant), DER, ROA

b. Dependent Variable: Pertumbuhan Laba

Sumber: Data diolah SPSS 26 (2021)

Berdasarkan Tabel 7, nilai koefisien determinasi (R Square) adalah sebesar 0,258, hal ini berarti variasi perubahan Pertumbuhan laba $(\mathrm{Y})$ dipengaruhi oleh Return On Asset $\left(\mathrm{X}_{1}\right)$ dan Debt to Equity Ratio $\left(\mathrm{X}_{2}\right)$, sebesar $25,8 \%$ sedangkan sisanya $74,2 \%$ dipengaruhi oleh faktor lain.

\section{Pembahasan}

\section{Pengaruh ROA Terhadap Pertumbuhan Laba}

Hasil pengujian Hipotesis $\mathrm{H} 1$ menunjukan bahwa ROA berpengaruh negatif dan tidak signifikan terhadap pertumbuhan laba, sehingga $\mathrm{H} 1$ ditolak. Hal tersebut dapat dibuktikan dari Nilai koefisien regresi ROA $\left(\mathrm{X}_{1}\right)$ adalah negatif, yaitu $-1,988$, yaitu setiap kenaikan ROA $\left(\mathrm{X}_{1}\right)$ sebesar $1 \%$ maka pertumbuhan laba akan turun sebesar $-1,988$ serta $t_{\text {-hitung }}(-, 1,592)<\mathrm{t}$-tabel $(1,998)$ atau sig t $(0,117)>0,05$; dengan demikian H1 ditolak dan Ho diterima, hal ini berarti tidak terdapat pengaruh antara Return On Asset terhadap Pertumbuhan Laba.

Hasil penelitian ini mendukung penelitian Fitriani (2021) Hasil penelitian menunjukan bahwa ROA tidak berpengaruh signifikan terhadap pertumbuhan laba. Penelitian Yanti (2017) juga menyatakan bahwa variabel return on asset tidak berpengaruh positif terhadap pertumbuhan laba.

\section{Pengaruh DER Terhadap Pertumbuhan Laba}

Hasil pengujian Hipotesis H2 menunjukan bahwa DER berpengaruh positif dan signifikan terhadap pertumbuhan laba, sehingga H2 diterima. Hal tersebut dapat dibuktikan dari Koefisien regresi DER $\left(\mathrm{X}_{2}\right)$ bernilai positif sebesar 0,950, yaitu setiap kenaikan DER $\left(\mathrm{X}_{2}\right)$ sebesar 1\% maka pertumbuhan laba akan meningkat sebesar 0,950 serta perhitungan t-hitung $(3,845)>$ t-tabel $(1,998)$ atau sig t $(0,00)>0,05$; dengan demikian H1 diterima dan Ho ditolak, hal ini berarti terdapat pengaruh antara Debt to Equity Ratio terhadap Pertumbuhan Laba.

Hasil penelitian ini sejalan dengan penelitian Mahaputra (2012) dimana hasil penelitian menunjukkan bahwa DER berpengaruh signifikan terhadap pertumbuhan laba. Penelitian lain seperti Juliana, Kasmawati, dan Tanjung (2020), juga menyatakan secara Debt To Equity, terbukti berpengaruh signifikan terhadap pertumbuhan laba.

\section{Pengaruh ROA dan DER Terhadap Pertembuhan Laba}

Hasil pengujian Hipotesis H3 menunjukan bahwa secara simultan ROA dan DER berpengaruh positif dan signifikan terhadap pertumbuhan laba, sehingga H3 diterima. Hal tersebut dapat dibuktikan dari nilai $F_{\text {hitung }}$ sebesar 10,800 dan $F_{\text {tabel }} 4,00$ sehingga $F_{\text {hitung }} 10,800$ $>F_{\text {tabel }} 4,00$ dan nilai sig $0,000<$ tingkat signifikan 0,05 . Serta nilai koefisien determinasi $(R$ Square) adalah sebesar 0,258 , hal ini berarti variasi perubahan Pertumbuhan laba (Y) dipengaruhi oleh Return On Asset $\left(\mathrm{X}_{1}\right)$ dan Debt to Equity Ratio $\left(\mathrm{X}_{2}\right)$, sebesar 25,8\% sedangkan sisanya $74,2 \%$ dipengaruhi oleh faktor lain.

Hasil penelitian ini sejalan dengan penelitian Juliana, Kasmawati, dan Tanjung (2020), yang menyatakan secara simultan Current Ratio, Debt To Equity, Total Asset TurnOver, dan Return On Asset terbukti berpengaruh signifikan terhadap pertumbuhan laba. Penelitian Megananda (2017) Hasil penelitian menunjukkan bahwa variabel current ratio, total asset turnover dan return on assets berpengaruh signifikan terhadap pertumbuhan laba. 


\section{Kesimpulan}

Berdasarkan hasil analisis data dan pembahasan yang telah dilakukan, dapat disimpulkan hal-hal sebagai berikut: Pengujian hipotesis ROA terhadap pertumbuhan laba, menghasilkan perhitungan t-hitung $(-1,592)<$ ttabel $(1,998)$ atau P-Value 0,117 dengan nilai koefisien regresi ROA sebesar - 1,988, dengan demikian H1 ditolak dan Ho diterima, hal ini berarti ROA mempunyai pengaruh negatif dan tidak signifikan terhadap Pertumbuhan Laba. Pengujian hipotesis DER terhadap pertumbuhan laba, menghasilkan perhitungan t-hitung $(3,845)>$ ttabel $(1,998)$ atau P-Value 0,00 dengan nilai koefisien regresi DER sebesar 0,950, dengan demikian $\mathrm{H} 2$ diterima dan Ho ditolak, hal ini berarti DER mempunyai pengaruh positif dan signifikan terhadap Pertumbuhan Laba. Pengujian hipotesis DER dan ROA Secara simultan terhadap pertumbuhan laba, menghasilkan perhitungan Fhitung sebanyak 10,800 dan Ftabel 4,00 sehingga $\mathrm{F}_{\text {hitung }} 10,800>\mathrm{F}_{\text {tabel }} 4,00$ dan nilai sig. $0,000<$ tingkat signifikan 0,05 , dengan demikian H3 diterima dan Ho ditolak, hal ini berarti DER dan ROA mempunyai pengaruh positif dan signifikan terhadap Pertumbuhan Laba.

\section{Daftar Pustaka}

Agustina, D. N., \& Mulyadi. (2019). Pengaruh Debt To Equity Ratio, Total Asset Turn Over, Current Ratio, Dan Net Profit Margin Terhadap Pertumbuhan Laba Pada Perusahaan Manufaktur Di Bursa Efek Indonesia. Jurnal Akuntansi, 6(1), 106-115.

Andriyani, I. (2015). Pengaruh Rasio Keuangan Terhadap Pertumbuhan Laba Pada Perusahaan Pertambangan Yang Terdaftar Di Bursa Efek Indonesia. Jurnal Manajemen dan Bisnis Sriwijaya. (13).

Dewi, I. K., dan Solihin, D. (2020). Pengaruh Current Ratio Dan Net Profit Margin Terhadap Harga Saham Pada Perusahaan Makanan Dan Minuman Yang Terdaftar Di Bursa Efek Indonesia (BEI) Periode 2015-2018. JURNAL ILMIAH FEASIBLE: Bisnis, Kewirausahaan \& Koperasi 2 (2), 183-191.

Fitriati. (2021). Pengaruh Return On Assets Dan Debt To Equity Ratio Terhadap Pertumbuhan Laba Pada Perusahaan Makanan Dan Minuman Yang Terdaftar Di LQ-45 Periode 20152019. Jurnal Manajemen Dan Organisasi Review (MANOR), 3(1), 68-77.

Ghozali. I. (2016). Aplikasi Analisis Multivariete Dengan Program IBM SPSS. Semarang: Badan Penerbit Universitas Diponegoro.

Gunawan, A., \& Wahyuni, S.F. (2013). Pengaruh Rasio Keuangan Terhadap Pertumbuhan Laba Pada Perusahaan Perdagangan Di Indonesia. Jurnal Manajemen dan Bisnis. (13).

Hidayat, M. (2014). Pengaruh Rasio Kesehatan Perbankan Terhadap Nilai Perusahaan (Studi Kasus Pada Perbankan yang Terdaftar di Bursa Efek Indonesia). Jurnal Ekonomi 4(1). 3455.

Ikatan Akuntansi Indonesia (2012), Standar Akuntansi Keuangan. Jakarta: Salemba Empat.

Irham, F. (2016). Pengantar Manajemen Keuangan. Bandung: Alfabeta.

Juliana, Kasmawati, \& Tanjung, I. (2020). Pengaruh Current Ratio, Debt To Equity Ratio, Total Asset Turnover, Dan Return On Asset Terhadap Pertumbuhan Laba Pada Perusahaan Subsektor Batubara Yang Terdaftar Di Bursa Efek Indonesia Periode 2016-2018. Jurnal Riset Manajemen Indonesia, 2(4), 376-384.

Kasmir. (2016). Analisis Laporan Keuangan. Jakarta: Raja Grafindo Persada.

Mahaputra, I.N. (2012). Pengaruh Rasio-Rasio Keuangan Terhadap Pertumbuhan Laba Pada Perusahaan Manufaktur Yang Terdaftar Di BEI. Jurnal Akuntansi dan Bisnis. (07).

Megananda, B. A. (2017). Pengaruh Current Ratio, Total Asset Turnover dan Return On Asset Terhadap Pertumbuhan Laba. Jurnal Ilmu Dan Riset Manajemen, 6(10), 1-16. 
Ningsih, A. A., Hasanah, N., \& Prihatni, R. (2017). Pengaruh Perbedaan Temporer Antara Laba Akuntansi Dan Pajak, Proprietary Cost, Dan Likuiditas Terhadap Pertumbuhan Laba, Jurnal UNJ, 12(1), 64-83

Nur. A. (2016). Faktor-faktor yang mempengaruhi Nilai Perusahaan pada Sektor Industri Food dan Beverages yang terdaftar di Bursa efek Indonesia (BEI) pada tahun 2011-2015. Skripsi Universitas Negeri Yogyakarta Diperoleh dari http://eprints.uny.ac.id/41199/1/2.

Safitri, A. M., \& Mukaram, M. (2018). Pengaruh ROA, ROE, dan NPM Terhadap Pertumbuhan Laba Pada Perusahaan Sektor Industri Barang Konsumsi Yang Terdaftar di Bursa Efek Indonesia. Jurnal Riset Bisnis Dan Investasi, 4(1), 25. https://doi.org/10.35697/jrbi.v4i1.990.

Solihin, D. (2019), Pengaruh Current Ratio dan Debt To Equity Ratio Terhadap Return On Asset (ROA) Pada PT Kalbe Farma, Tbk. KREATIF: Jurnal Ilmiah Prodi Manajemen Universitas Pamulang 7 (1), 115-122.

Sukmawati, S. (2017). Pengantar Pemodelan Keuangan Dan Analisis Pasar Modal (Edisi 1). Yogyakarta: Andi Offset.

Susanti, N.H. (2014). Analisis Rasio Keuangan Untuk Memprediksi Pertumbuhan Laba Perusahaan Otomotif Di BEI. Jurnal Ilmu dan Riset Manajemen. (03).

Yanti, N. S. 2017. Dampak Kinerja Keuangan Terhadap Pertumbuhan Laba (Studi Kasus Pada Perusahaan Makanan dan Minuman Yang Terdaftar Di Bursa Efek Indonesia Tahun 2010-2016). Jurnal Ekonomi \& Bisnis Dharma Andalas, 19, 220-234. 